\title{
Assessment and Predicting of LULC by Kappa Analysis and CA Markov model using RS and GIS Techniques in Udham Singh Nagar District, India
}

THANGAVELU ARUMUGAM ( $\square$ thangavelgis@gmail.com )

Kannur University

RAM LAKHAN YADAV

G.B. Pant Institute of Himalayan Environment and Development

\section{SAPNA KINATTINKARA}

PSG college of Arts and Science

\section{Research Article}

Keywords: Accuracy assessment, CA MARKOV model, GIS, LULC, Uttarkhand

Posted Date: January 13th, 2021

DOl: https://doi.org/10.21203/rs.3.rs-141832/v1

License: (c) (1) This work is licensed under a Creative Commons Attribution 4.0 International License.

Read Full License 


\title{
Assessment and predicting of LULC by Kappa Analysis and CA Markov model using RS and GIS Techniques in Udham Singh Nagar District, India
}

\author{
Thangavelu Arumugam ${ }^{1,2 *}$, Ram Lakhan Yadav $^{1}$, Sapna Kinattinkara ${ }^{3}$ \\ 1,2* Department of Environmental Studies, Mangattuparamba campus, Kannur University, Kerala - 670567 \\ ${ }^{1}$ G.B. Pant National Institute of Himalayan Environment \& Sustainable Development, Uttarkhand -263643 \\ ${ }^{3}$ Department of Environmental Science, PSG College of Arts and Science, Coimbatore - 641014.
}

Corresponding author: ${ }^{1,2 *}$ Thangavelu Arumugam

E-mail: thangavelgis@gmail.com

\begin{abstract}
In this study an attempt to generate the LULC maps and investigate change detection analysis over a period of 22 years using Landsat satellite images of 1994, 2000, and 2016 and to predict the LULCC for the year 2016-2032 using CA Markov model in Udham Singh Nagar district, Uttarkhand. Satellite images of Landsat 5 TM, Landsat 7 ETM+, and Landsat 8 OLI sensor of nominal spatial resolution $30 \mathrm{~m}$ were used. Supervised image classifications with the help of parallel pipe algorithm were used in this study. The validity of the Cellular Automata Markov model were used to predict future (16 years) LULC of 2032. The estimation includes two modules to predict the future land use pattern of the study area such as MARKOV and CA-MARKOV model/modules. Commonly, the accuracy of the classification results is assessed by the error matrix calculation. The result of overall change detection indicates agriculture, forest, water body and fallow land are decreased by $121.75 \mathrm{Km}^{2}(14 \%), 44.70 \mathrm{Km}^{2}$ (5\%), $38.91 \mathrm{Km}^{2}(4.5 \%)$ and $230.71(26.5 \%)$; settlement and river sand are increased by $379.89 \mathrm{Km}^{2}(44 \%)$ and $56.18 \mathrm{Km}^{2}(6 \%)$. The study has an overall classification accuracy $76.84 \%$, and standard kappa coefficient value (K) of 0.722 . The model predicts the future change detection in agriculture $32 \%$, forest $38 \%$, fallow land $5 \%$, settlement $20 \%$, water body $3 \%$, and river sand is $2 \%$. This study is very effective for future LULC prediction that is helpful in urban development planning and the field of management of natural resources.
\end{abstract}

Keywords: Accuracy assessment, CA MARKOV model, GIS, LULC, Uttarkhand.

\section{Introduction}

Land is one of the most important natural resources, as life and various development activities are based on land surface (Lambin et al. 2001; Dai et al. 2001; Deep and Saklani 2014; Karimi et al. 2018). Land cover change has 
been recognized the essential drivers of changes in ecosystems and their services also predicting the changes in the future are unavoidable (Turner and Ruscher 2004; Du et al. 2016; Haque and Basak 2017). These changes result from population growth and migration of rural people to urban areas and the unsustainable development of agriculture for economic opportunities (Deep and Saklani 2014; Misra, and Vethamony 2015; Rawat and Kumar 2015; Hyandye and Martz 2017). Human interference on the environment can be determined by Land use and land cover changes (LULCC) (Gounaridis et al. 2019).

LULCC detection has been used in a number of research studies for few recent years. The changes in different land use pattern on the land surface on a specific part of the land or country or region (Rawat et al. 2014). A number of LULC models have created to fulfill the needs of the researches to know more about the LULCC happened on earth (Lantman et al. 2011). LULC is to identify the social, economic, and cultural causes which lead to changes in land use pattern can easily make proposals for the suitable use of land and its patterns of development (Lo and Yang 2002; Rawat et al. 2013). The outcome of LULC studies commonly used for policy decision making associated to land-use (Mallampalli et al. 2016).

Remote sensing and GIS plays an important role by opening a number of ways to acquire data for LULC mapping (Jayakumar and Arockiasamy 2003). Urbanization is a process which led to different types of land use pattern on the surface of the earth (Chilar 2000). Land cover is the resources on the land surface that is natural or man-made (Honnay et al. 2003; Quan et al. 2006; Ge et al. 2007; Luciana et al. 2007; Fikir et al. 2009). Land use is the usage of land resources for various purposes (Gautam et al. 2003; Patma et al. 2004; Guan et al. 2008). Soil, water bodies, forests, and mountains etc. are the land cover when human beings using these land resources several purposes it is land use (Rahman et al. 2011; Tripathi and Kumar 2012).

The several investigators national and international level has approached for LULC study in different ways. Land use refers to the purpose for which a human change their natural land cover and therefore can directly affect the by human activities (Patma et al. 2004; Zhou et al. 2008; Rawat et al. 2013; Rawat et al. 2014). LULCC are very much influenced by human interference and natural phenomenon like agriculture, population growth, consumption, patterns, urbanization and economic development etc. (Gautam et al. 2003; Dadashpoor et al. 2018). The change detection is the process by which one can easily find out differences between the imagery by observing at different times (Heuvelink and Burrough 2002). Daniel et al. (2002) analyzed LULC change detection methods and made use 
of five methods in different ways. Yuan et al. (2005) have observed the land cover change using multi-temporal Landsat TM data in Twin cities metropolitan area. Rawat and Manishkumar (2015) have studied the LULCC that have taken place in Lagos for the last two decades due to the rapid urbanization.

The accuracy assessment estimation is an important final step in the processing of remote sensing data. Accuracy creates the information value of the resulting data to a user. A large number of the recent investigation applying accuracy assessments uses kappa coefficient $(\mathrm{K})$ based indices, and overall accuracy as an indication of the validity of the classification algorithm. Though, recent developments in accuracy assessment methodology have pointed out the effect of the kappa indices (Pontius and Millones 2011). There are numerous authors have performed evaluate on classification accuracy assessment (Congalton 1991; Janssen and van der Wel 1994). The Kappa coefficient is an error matrix of overall accuracy assessment which is obtains since non-diagonal elements information. Kappa analysis is established as an immense method for analyzing a single error matrix and comparing the differences between different error matrices (Smits et al. 1999, Foody 2004). Based on accuracy assessment error matrix have analysed for better presentation conventional error matrix (Hardin and Shumway 1997, Stehman 2004; Verma et al. 2020).

The Markov model can identify the changes dynamically of different landscapes pattern that is found on the surface of the earth but it cannot deal with changes in the pattern (Clarke et al. 1997; Batty et al. 1999; Weng 2002; Myint and Wang 2006; Ye and Bai 2008; Courage et al. 2009; Mubea et al. 2011). The application of CA Markov model applied for the geospatial environmental modeling in various aspects (Ghosh et al. 2017). In earlier several researchers have approached the different manner of CA models used for simulating the urban growth processes (Deal and Schunk 2004; Arsanjani et al. 2018). The majority of the CA studies have concluded that the transition potential models include logistic regression, random forests, and artificial neural networks (Li and Yeh 2001; Tayyebi et al. 2014).

CA-Markov model were used for several studies to identify the simulation of land use pattern (Kamusoko and Gamba 2015). Hyandye and Martz (2017) found the CA Markov model can evaluate the efficiency of the study. CA-Markov model in Arasbaran biosphere reserve-Iran was effectively applied by Parsa et al. (2016) to predict the future LULC that helps the planners and policy makers to make proper decisions for future land use challenges. When comparing the CA-Markov model and Multi-layer Perceptron-Markov Chain (MLP-MC) models LULC 
urban growth simulation were analyzed and predict the future change in Atakum Samsun in Turkey (Ozturk, 2015). Regmi et al. (2014) comparing the CA-Markov and GEOMOD models were analyzed the LULC dynamics model in Phewa lake watershed in Nepal. This study was combined top-down and bottom-up dynamics of land-use modeling by using Markov model Sohl and Sayler (2008).

CA Markov model takes the land-use changes and predicted future changes use (Dadhich and Hanaoka 2010; Yu et al. 2011; Halmy et al. 2015; Karimi et al. 2018). For this study, the CA model was supported by the future land use simulation model that combines the LU and LC at different scale to provide the multiple tasks (Li et al. 2017; Liu et al. 2017; Liang et al. 2018). To identify and calculate error, quantitative evaluations are used (Rwanda and Ndambuki 2017; Anjan and Arun 2019). The error matrix has become a rising criterion for estimation of image classification accuracy. The error matrix was an essential element of this research and used in a variety of landchange studies (Mishra et al. 2019). The main aim of the present study is to generate the LULC maps and investigate change detection analysis over a period of 22 years using Landsat satellite images of 1994, 2000, and 2016, and to predict the LULCC for the year 2016-2032 using CA Markov model for the study.

\section{Study Area}

The Udham Singh Nagar district is located in the state Uttarkhand sharing borders with Uttar Pradesh on south and Nepal on east. It is located approximately latitude $28^{\circ} 53^{\prime} \mathrm{N}$ and $29^{\circ} 23^{\prime} \mathrm{N}$ and laterally extends between longitude $78^{\circ} 45^{\prime} \mathrm{E}$ and $80^{\circ} 08^{\prime} \mathrm{E}$. The maximum temperature in the district goes up to $42^{\circ} \mathrm{C}$ during the summer and the minimum temperature is between 1 and $4^{\circ} \mathrm{C}$. The area of elevation is $298 \mathrm{~m}(978 \mathrm{ft})$. It is known as Gateway to Kumaun hills. Prior it was part of Nainital district, but was separated as it was fall in Tarai region of the state, and it also known "food bowl of the state". The study area map is shown in Figure1.

\section{Materials and Methodology}

\subsection{Data used and Image classification}

The Landsat datasets that are used in the study includes Landsat 5 Thematic Mapper (TM) of 1994, Landsat 7 Enhanced Thematic Mapper Plus (ETM+) of 2000, and Landsat 8 Operational Land Imager (OLI) of 2016. All the three of Landsat datasets have a spatial resolution of $30 \mathrm{~m}$. The datasets downloaded from USGS Website (https://earthexplorer.usgs.gov/) (Table 1). The images acquired were with less than 10\% cloud cover for all the scenes. Remote sensing software such as ERDAS and ArcGIS environment were used for image processing. The 
radiometric correction was done and subsets from each of the Landsat sensors for different years classified with supervised image classification. Besides these satellite images, Google Earth was also used for ground truthing. For image processing signature file creation tool was used for developing six classes of LULC. Settlement, water body, forest, fallow land, river sand, and agriculture were identified and classified for 22 years of 1994, 2000, and 2016 (Brown et al. 2013; Gounaridis et al.2016; Verburg et al. 2016).

\subsection{Accuracy Assessment Estimator and Kappa coefficient}

The accuracy assessment estimator is the most important and it is the last stage in classification process of the images (Foody 2002). It is to quantitatively assess how efficiently the pixels were sampled into correct land cover classes. There are different accuracy assessment model, among that the error matrix or confusion matrix has become the most efficient method for deducting the accuracy of classification obtained from remotely sensed data (Congalton 1991; Congalton and Mead 1983; Sanjoy Roy et al., 2015). The accuracy assessment methods were included the standard kappa coefficient, overall accuracy, producer's accuracy and user's accuracy. The overall accuracy estimator calculates the number of pixels classified accurately in the image. The image was classified into six classes settlement, water body, forest, fallow land, river sand, and agriculture (Table 3). The user's accuracy measures how often the class on the map actually is present on the ground. The producer's accuracy measures the number of pixels classified to a class which accurately fit in to that class only. A wide field survey was performed and Landsat OLI images used to collect ground truth (validation) data for 2016. For the accuracy assessment, totally 285 ground truth points were generated using the stratified random sampling method over the study area for 2016 LULC image. Table 3 shows the relationship between ground truth data and the consequent classified data obtained through confusion matrix (Pontius and Millones 2011). An accurate Kappa statistic for the stratified random was find out by using the following equation (Petropoulos et al. 2015) (1).

$$
\text { Kappa coefficient }=\frac{(T \times C)-G}{T^{2}-G}
$$

Where, $\mathrm{T}$ is the test pixels, $\mathrm{C}$ is the correctly classified pixels observations, $\mathrm{G}$ is the sum of multiplied total value.

The overall accuracy or total accuracy computed by dividing the sum of the values along the major diagonal by the total number of reference pixels. The traditional accuracy assessment methods included the standard kappa coefficient followed by overall accuracy eq (2), Producers accuracy eq (3), and Users accuracy eq (4) 


$$
\begin{gathered}
\text { Overall Accuracy }=\left(\frac{1}{\mathrm{w}}\right) \sum_{\mathrm{i}=1}^{\mathrm{T}} n_{\mathrm{ii}} \\
\text { Producer's Accuracy }=\left(\frac{\mathrm{n}_{\mathrm{ii}}}{\mathrm{n}_{\mathrm{icol}}}\right) \\
\text { User's Accuracy }=\left(\frac{\mathrm{n}_{\mathrm{ii}}}{\mathrm{n}_{\text {irow }}}\right)
\end{gathered}
$$

Where, $\mathrm{n}_{\mathrm{ii}}$ is the number of suitably classified pixels, $\mathrm{N}$ is the total number of pixels, $\mathrm{r}$ is the number of rows, and $n_{i}$ col and $n_{i}$ row are the column and row total were respectively.

\subsection{Cellular Automata (CA) model}

The prediction model which is used in the present study for cellular automata (CA) model. It is broadly applied to the simulation of monitoring, complex systems, for instance urban growth modeling, ecological modelling, and geographical simulation changes (Clarke and Gaydos 1998; Sohl and Sayler 2008; van Asselen and Verburg 2013). For this study, the CA model was applied to predict the amount of the LULC and the stability of future development in the area of importance (Weng 2012; Subedi et al. 2013; Parsa et al. 2016). For this model initially used land use modelling by (Burnham, 1973). CA model divided into two simulation periods such as model calibration and validation and scenario simulation maps with reference maps is the most efficient way (Gounaridis et al. 2018). Markov chain model have explained the LULC change from one time to another in order to predict future change (Behera et al 2012; Kumar et al. 2014). The prediction of land use changes in calculation described in equation (5)

$$
S(t, t+1)=P_{i j} \times S(t)
$$

where $S(t)$ is the system status at time, $S(t, t+1)$ is the system status at time of $t+1$; Pij is the Transition probability matrix.

The error matrix allows to find a range of accuracy metrics from the data. In this study, thematic accuracy was measured by using an overall accuracy and error. For this instance, Markov chain analysis the image separate into two time periods of base imagery and second one on which the prediction is based on the other imagery. The first order of Markov model (Usher 1992) assumes that to predict the current nature of the system at time $t+1$. The core of the Markov model is the transition matrix $\mathrm{P}$, that summarizes the chances of a cell in cover type $\mathrm{i}$ which are change to cover type $\mathrm{j}$ during a time step. The equation for the Markov model is given below (eq. 6, 7, 8 \& 9).

$$
x_{t}=\left[x_{1} x_{2} x_{3} \ldots\right]
$$


Where $\mathrm{x}_{\mathrm{i}}$ is the proportions of cells in type $\mathrm{i}$ at time $\mathrm{t}$, a Markov model is projected.

$$
x_{t+1} x_{t} p
$$

The state vector post multiplied by the transition matrix. The time $t+2$ is continued for following projection

$$
x_{t+2}=x_{t+1} p=x_{t} p^{2}
$$

In general, the state of the system at time $\mathrm{t}=$ tare given by:

$$
x_{t+k}=x_{t} p^{k}
$$

Where $\mathrm{x}_{\mathrm{t}}$ is the initial condition of the map. Therefore, the model can be projected into the future simply by iterating the process through matrix operation. At present the model is basically used in predicting LULC models (Muller and Middleton 1994; García-Mora et al. 2010; Zhang et al. 2011; Kumar et al. 2014; Rahel Hamad et al. 2018; Floris et al. 2019). The predicted imagery shows that the significant change in all the feature class. The overall methodology of the LULC CA Markov Model study is shown in Figure 2.

\section{Result and discussion}

\subsection{Classification of imagery $(1994,2000 \& 2016)$}

The classification of the imagery is done by the supervised image classification and in this classification used parametric rule and used parallel piped algorithm as it was the best suited algorithm in this study. The total areas of land-use pattern in the district of Udham Singh Nagar for the year 1994 were presented in figure 3. The agricultural land category involves land under crops, fallow, plantations, and aquaculture. The area under agriculture has $1019.14 \mathrm{~km} 2(39 \%)$ yield the largest of the area in 1994. Multi-storeyed and deciduous forest covers with a number of matured trees in the upper canopy and less dense forests shed their leaves during the dry season were presented in this area. The forest shows that the area is covered the $806.34 \mathrm{~km}^{2}(31 \%)$. The fallow land is presently cultivated land that is not started or seeded for one or more increasing seasons. The fallow land was obtained in the area of $417.08 \mathrm{~km}^{2}(16 \%)$ as shown in figure 7. The remaining feature classes settlement was observed in the area of 196.89 $\mathrm{km}^{2}(8 \%)$, it includes urban and rural settlements, transportation, communication, and recreational utilities. Water bodies group comprises areas with surface water in the form of ponds, lakes, drains, and canals etc. The total area covered by water bodies in 1994 was $106.63 \mathrm{~km}^{2}(4 \%)$. The river sand is a natural material which is presented in 
tiny chemical properties such as sandy soils, some portion of silt, clay, and organics. The river sand was observed in $40.31 \mathrm{~km}^{2}(2 \%)$ as shown in Table 2.

The classification of the year 2000 imagery were categorized and presented in figure 4 . The area under agriculture is decreased by $38 \%$ presented the area of $984.13 \mathrm{~km}^{2}$, forest area is decreased by $30 \%$ displaying the area of 778.76 $\mathrm{km}^{2}$, fallow land is decreased by $14 \%$ noticing the area of $351.53 \mathrm{~km}^{2}$. The water body is presented the $3 \%$, while the water body is decreased by $85.76 \mathrm{~km}^{2}$. The area of settlement is increased by $13 \%$, showing area of $326.04 \mathrm{~km}^{2}$, and river sand is increased by $2 \%$, showing area $55.17 \mathrm{~km}^{2}$ as presented in figure 8 .

The classification of 2016 satellite images was used supervised image classification. The process of classification shows the significant changes in the feature classes of this area. Figure 5 shows that the agriculture area is decreased by $35 \%$, showing area of $897.39 \mathrm{~km}^{2}$, while the area under forest is decreased by $30 \%$, showing area of $761.64 \mathrm{~km}^{2}$, fallow land is decreased by $7 \%$, area $186.37 \mathrm{~km}^{2}$, settlement showing change $22 \%$, the area is $576.78 \mathrm{~km}^{2}$, water body shows the change negatively with change of $2 \%$, the area is $62.72 \mathrm{~km}^{2}$, while the area of river sand is increased in the course of 23 years, change is $4 \%$, the area is 96.49 were observed in Table 2.

\subsection{Overall Change detection and Kappa coefficient}

In overall change detection agriculture land is decreased by $121.75 \mathrm{~km}^{2}(14 \%)$, forest area is declined by $44.70 \mathrm{~km}^{2}$ (5\%), fallow land reduced by $230.71 \mathrm{~km}^{2}(26.5 \%)$, settlement is increased by $379.89 \mathrm{~km}^{2}$ (44\%), and water body decreased by $230.71 \mathrm{~km}^{2}(4.5 \%)$, river sand is increased by $56.18 \mathrm{~km}^{2}(6 \%)$ over the period of 22 years as presented in Table 2). Table 4 shows that the relationship between ground truth (validation) data and the selected classified data obtained through error matrix analysis. The results from accuracy assessment shows an overall accuracy obtained from the random sampling process for the image (2016) of 76.84\%. User's accuracy ranged from $71.42 \%$ to $83.05 \%$ while producer's accuracy ranged from $75 \%$ to $77.7 \%$. The measure of producer's accuracy reveals that the accuracy of prediction of the particular class. User's accuracy reveals that the constancy of the group to the user. It is the more relevant measure of the classification's actual utility in the ground truth field. Fallow land was found to be more reliable with $77.08 \%$ of user accuracy. The study has an overall classification accuracy of $76.84 \%$ and the kappa coefficient value $(\mathrm{k})$ was found 0.7203 .

\subsection{Future change detection for 2032}


The change detection pattern for next 16 years (2032) both area and percentage were presented in table 3 . The result shows that both increase and decrease changes occurred in the land use/cover pattern of the study area. During the last three decades the agriculture, forest, fallow land, and water body in the study area have decreased, settlement and river sand was increased in the study area. The analysis reveals that agriculture is declined by $847.78 \mathrm{~km}^{2}$ (33\%), forest is increased by $1021.78 \mathrm{~km}^{2}(39 \%)$, fallow land is decreased by $22.08 \mathrm{~km}^{2}(1 \%)$, and settlement $533.87 \mathrm{~km}^{2}(21 \%)$, water body $55.93 \mathrm{~km}^{2}(4 \%)$ and river sand $55.93 \mathrm{~km}^{2}(2 \%)$ were increased in future change detection is shown in figure 6. The study is to understand the future changes for different LULC categories by using the different Landsat datasets.

The error matrix was preferred assess the accuracy of the classified map of 1994. Landsat 5 TM of 1994 was used for accuracy assessment, 285 stratified random points in each class were created in Table 4. The LULC maps produced from satellite images for the study area consists of six thematic land cover classes. In favour of accuracy assessment a totally 285 reference sites were used validation for the land-cover type. Out of these reference sites, agriculture (63), forest (55), fallow land (48), settlement (39), water body (44), and river sand (36). These reference sites subsequently compared to classified results created from the satellite images.

The diagonal elements of the error matrix represent areas that were exactly classified. It is indicative of the accuracy classification. In the study, out of the 63 agriculture reference sites only 49 of these were correctly identified in the classified imagery. Similarly, out of 55 forest reference sites 42 were exactly recognized, out of 48 fallow land reference sites 37 were observed, out of 39 settlement reference sites 30 were strongly presented, out of 44 water body reference sites 33 were accurately received, and out of 36 river sand reference sites 28 were accurately received in Table 4. The off-diagonal elements inform that how to improve the remote sensing classification and time have to spent examining these errors to determine where the most errors occurred in the classification.

\section{Conclusion}

The study concluded that in the near future settlement will be growing at a rapid rate. Migration and rapid industrialisation are acting as a major factor in the development of the district. Forest cover will be increasing in the future, but the area of agriculture land is decreased as compared to other areas. Predicted map shows the overall accuracy of accurately $77 \%$ with the help of CA MARKOV model and the use of Markov and CA Markov modules. The classification results clearly demonstrate that satellite images very supportive for extracting LULC for change 
detection considering the level of classification. It is nonetheless to state that there is a great impact of spatial resolution (and spectral resolution as well) on any kind of remote sensing (RS) and GIS applications. This impact of the resolution was also evident in this study. The classification accuracy was fairly related to the resolution of the image. A good accuracy level was also achieved during the classification (88\%) for 1994 imagery, (84\%) for 2000, and $(86 \%)$ for 2016.

Once the classification (1994-2016) has done, checked the accuracy of each classified images for proving how well is the classification. Then by applying change detection observed the changes between the three different images. The Udham Singh Nagar district was a chosen as a study area to monitor land use/land cover dynamics over a period of 22 years. During 1994 to 2016, the study area has been divided into six major categories such as settlement, forest, agriculture, river sand, water body, and fallow land. CA Markov chain method is very effective for future LULC prediction that is helpful in the field of management of natural resources.

\section{Acknowledgement}

The authors sincerely thank to the Kannur University, Kerala for their support for preparing manuscript.

\section{References}

1. Anjan Roy, Arun B Inamdar (2019) Multi-temporal Land Use Land Cover (LULC) change analysis of a dry semi-arid river basin in western India following a robust multi- sensor satellite image calibration strategy. Heliyon 5 e01478. doi: 10.1016/j.heliyon.2019.e01478.1-20.

2. Arsanjani JJ, Fibæk CS, Vaz E (2018). Development of a cellular automata model using open source technologies for monitoring urbanisation in the global south: the case of Maputo, Mozambique. Habitat International, 71, 38-48. doi:10.1016/j.habitatint.2017.11.003.

3. Behera MUD, Borate SN, Panda SN, Behera PR, Roy PS (2012) Modelling and analyzing the watershed dynamics using Cellular Automata (CA)-Markov model-A geo-information based approach. Journal of earth system science, 121, 1011-1024.

4. Brown DG, Verburg PH, Pontius Jr RG, Lange MD (2013) Opportunities to improve impact, integration, and evaluation of land change models. Current Opinion in Environmental Sustainability 5:452-457. 
5. Burnham B.O (1973) Markov intertemporal land use simulation model. Journal of Agricultural and. Applied Economics, 5, 253-258.

6. Clarke KC, Hoppen S, Gaydos L (1997) A self-modifying cellular automaton model of historical urbanization in the San Francisco Bay Area. Environ Plan B: Plan Design 24:247-261.

7. Clarke KC, Gaydos, LJ (1998) Loose-coupling a cellular automaton model and GIS: long-term urban growth prediction for San Francisco and Washington/Baltimore. International Journal of Geographical Information Science, 12 (7), 699-714. doi:10.1080/136588198241617.

8. Congalton R (1991) A review of assessing the accuracy of classifications of remotely sensed data", Remote Sensing of Environment, 37 (1): 35-46.

9. Congalton R, Mead R (1983) A quantitative method to test for consistency and correctness in photo interpretation", Photogrammetric Engineering and Remote Sensing, 49 (1): 69-74.

10. Dadashpoor H, Azizi P, Moghadasi M (2018) Land use change, urbanization, and change in landscape pattern in a metropolitan area. Science of the Total Environment. 655:707-719. doi:10.1016/j.scitotenv.2018.11.267.

11. Dadhich PN, Hanaoka S (2010) Remote sensing, GIS and Markov's method for land use change detection and prediction of Jaipur district. Journal of Geomatics 4:9-15.

12. Dai FC, Lee CF, Zhang XH (2001) GIS-based geo-environmental evaluation for urban land-use planning: a case study. Engineering Geology 61:257-271.

13. Daniel LC, James DH, Emily HW, Mingjun S, Zhenkui Z (2002) A Comparison of Land use and Land cover Change Detection Methods, ASPRS-ACSM Annual Conference and FIG XXII Congress, pp.2

14. Deal B, Schunk D (2004) Spatial dynamic modeling and urban land use transformation: a simulation approach to assessing the costs of urban sprawl. Ecological Economics, 51(1-2), 79-95.

15. Deep S, Saklani A (2014) Urban sprawl modeling using cellular automata. The Egyptian Journal of Remote Sensing and Space Science. 17(2):179-187. https://doi.org/10.1016/j.ejrs.2014.07.001.

16. Fikir A, Nurhussen T, Jan N (2009) The impacts of watershed management on land use and land cover dynamics in Eastern Tigray (Ethiopia). Resource Conservation. Recycle 53:192-198. 
17. García-Mora B, Santamaría C, Navarro E, Rubio G, García-Mora B (2010) Modeling bladder cancer using a Markov process with multiple absorbing states. Mathematical and Computer Modelling 52 (7-8):977-982, https://doi:10.1016/j.mcm.2010.02.036.

18. Gautam AP, Webb EL, Shivakoti GP (2003) Land use dynamics and landscape change pattern in a mountain watershed in Nepa1. Agriculture, Ecosystem \&Environment 99:83-96.

19. Gounaridis D, Chorianopoulos I, Koukoulas S (2018) Exploring prospective urban growth trends under different economic outlooks and land-use planning scenarios: The case of Athens. Applied Geography 90:134144.

20. Gounaridis D, Chorianopoulos I, Symeonakis E, Koukoulas S (2019) A Random Forest-Cellular Automata modelling approach to explore future land use/cover change in Attica (Greece), under different socioeconomic realities and scales, Science of the Total Environment 646, 320-335, https://doi.org/10.1016/j.scitotenv.2018.07.302.

21. Guan D, GAO W, Watari K (2008) Land use change of Kitakyushu based on landscape ecology and Markov model. Journal of Geographical Science 18:455-468, https://doi.org/10.1007/s11442-008-0455-0.

22. Halmy MWA, Gessler PE, Hicke JA, Salem BB (2015) Land use/land cover change detection and prediction in the north-western coastal desert of Egypt using Markov-CA. Applied Geography 63:101-112.

23. Haque MI, Basak R (2017) Land cover change detection using GIS and remote sensing techniques: a spatiotemporal study on Tanguar Haor, Sunamganj, Bangladesh. Egyptian Journal of Remote Sensing Space Science $20: 251-263$.

24. Hardin PJ, Shumway J M. (1997) Statistical significance and normalized confusion matrices. Photogrammetric Engineering and Remote Sensing, 63: 735-740.

25. Heuvelink GBM, Burrough PA (2002) Developments in statistical approaches to spatial uncertainty and its propagation. International Journal of Geographical Information Science 16(2):111-113.

26. Honnay O, Piessens K, Van Landuyt (2003) Satellite based land use and landscape complexity indices as predictors for regional plant species diversity. Landscape and Urban Planning 63:241-250.

27. Hyandye C, Martz LW (2017) A Markovian and cellular automata land-use change predictive model of the Usangu Catchment. International Journal of Remote Sensing 38:64-81. 
28. Jayakumar S, Arockiasamy DI (2003) Land Use/Land Cover Mapping and Change Detection in part of Eastern Ghats of Tamil Nadu using Remote Sensing and GIS. Journal of the Indian Society of Remote Sensing 31:70-78.

29. Kamusoko C, Gamba J (2015) Simulating urban growth using a Random Forest-Cellular Automata (RF-CA) model. ISPRS International Journal of Geo-Information, 4 (2), 447-470. doi:10.3390/ijgi4020447.

30. Karimi H, Jafarnezhad J, Khaledi J (2018) Monitoring and prediction of land use/land cover changes using CAMarkov model: a case study of Ravansar County in Iran Arabian Journal of Geosciences 11:592, https://doi.org/10.1007/s12517-018-3940-5.

31. Kumar S, Radhakrishnan N, Mathew S (2014) Land use change modelling using a Markov model and remote sensing. Geomatics, Natural Hazards and Risk, 5(2):145-156. https://doi:10.1080/19475705.2013.795502.

32. Li X, Chen G, Liu X, Liang X, Wang S, Chen Y, Pei F, Xu X (2017) A new global land-use and land-cover change product at a 1-km resolution for 2010 to 2100 based on human-environment interactions. Annals of the American Association of Geographers, 107 (5), 1040-1059. doi:10.1080/24694452.2017.1303357.

33. Li X, Yeh GO (2001) Calibration of cellular automata by using neural networks for the simulation of complex urban systems. Environment \& Planning A, 33(8), 1445-1462. doi:10.1068/a33210.

34. Liang, X, Liu X, Li D, Zhao H, Chen G (2018) Urban growth simulation by incorporating planning policies into a CA-based future land-use simulation model. International Journal of Geographical Information Science, 32 (11), 2294-2316. doi:10.1080/13658816.2018.1502441.

35. Liu, X, Lianga X, Lib X, Xua X, Oua J, Chenb,T, Lic S, Wanga S, Pei F (2017) A future land use simulation model (FLUS) for simulating multiple land use scenarios by coupling human and natural effects. Landscape and Urban Planning, 168, 94-116. doi:10.1016/j.landurbplan.2017.09.019.

36. Lo CP, Yang X (2002) Drivers of land-use/land-cover changes and dynamic modeling for the Atlanta, Georgia metropolitan area. PE \& RS-Photogrammetric Engineering \& Remote Sensing, 68(10):1073-1082.

37. Mishra PK, Rai A, Rai SC (2019) Land use and land cover change detection using geospatial techniques in the Sikkim Himalaya, India. The Egyptian Journal of Remote Sensing and Space Sciences, 1-11. https://doi.org/10.1016/j.ejrs.2019.02.001. 
38. Misra A, Vethamony P (2015) Assessment of the land use/land cover (LU/LC) and mangrove changes along the Mandovi-Zuari estuarine complex of Goa, India. Arabian Journal of Geosciences 8:267-279.

39. Mubea K, Ngigi T, Mundia C (2011) Assessing application of Markov chain analysis in predicting land cover change: a case study of Nakuru municipality. Journal of Agriculture Science and Technology 1(2):126-144.

40. Muller MR, Middleton J (1994) A Markov model of land-use change dynamics in the Niagara Region, Ontario, Canada. Landscape Ecology 9: (2):151-157.

41. Ozturk, D (2015) Urban growth simulation of atakum (Samsun, Turkey) using cellular automata-Markov chain and multi-layer perceptron-markov chain models. Remote Sensing. 7, 5918-5950; https://doi.org/10.3390/rs70505918.

42. Parsa VA, Yavari A, Nejadi A (2016) Spatio-temporal analysis of land use/land cover pattern changes in Arasbaran Biosphere Reserve: Iran. Modeling Earth Systems and Environment, 2, 1-13.

43. Patma V, Sukaesinee S, Viriya, Somjai S, Vidhaya TG, Vichai S (2004) From forestto farmfields: changes in land use in undulating terrain of northeast Thailand at different scales during the past century. Journal of Southeast Asian Studies 41:444-472.

44. Petropoulos GP, Kalivas DP, Georgopoulou IA, Srivastava PK (2015) Urban vegetation cover extraction from hyperspectral imagery and geographic information system spatial analysis techniques: case of Athens, Greece. J Appl Remote Sens 9(1):096088.

45. Pontius RG Jr, Millones M (2011) Death to Kappa: birth of quantity disagreement and allocation disagreement for accuracy assessment. Int J Remote Sens 32(15):4407-4429.

46. Quan BN, Chen JF, Qiu HL (2006) Spatial-temporal pattern and driving forces of land use changes in Xiamen. Pedosphere, 16(4):477-488.

47. Rahel Hamad, Heiko Balzter and Kamal Kolo (2018) Predicting Land Use/Land Cover Changes Using a CAMarkov Model under Two Different Scenarios. Sustainability 10(10):1-23, https://doi: 10.3390/su10103421.

48. Rahman A, Kumar S, Fazal S and Siddiqui M A (2011) Assessment of land use/land cover change in the NorthWest District of Delhi using remote sensing and GIS techniques. Journal of Indian Society of Remote Sensing 40:689-697, https://doi: 10.1007/s12524-011-0165-4. 
49. Rawat J, Kumar M (2015). Monitoring land use/cover change using remote sensing and GIS techniques: a case study of Hawalbagh block, district Almora, Uttarakhand, India. Egyptian Journal of Remote Sensing Space Science 18:77-84.

50. Rawat JS, Biswas V, Kumar M (2013) Changes in land use/cover using geospatial techniques-A case study of Ramnagar town area, district Nainital, Uttarakhand, India. Egyptian Journal of Remote Sensing Space Science 16:111-117

51. Rawat JS, Manish Kumar, Vivekananda Biswas (2014) Land use/cover dynamics using multitemporal satellite imagery - A case study of Haldwani town area, district Nainital, Uttarakhand, India. International Journal of Geomatics and Geosciences, 4(3):536-543.

52. Regmi R, Saha S, Balla M (2014) Geospatial analysis of land use land cover change predictive modeling at Phewa Lake Watershed of Nepal. International Journal of Current Engineering and Technology, 4, $2617-2627$.

53. Rwanga SS, Ndambuki JM (2017) Accuracy Assessment of Land Use/Land Cover Classification Using Remote Sensing and GIS. International Journal of Geosciences, 8, 611-622.

54. Sanjoy Roy, Kaniz Farzana, Mossammat Papia, Mehedi Hasan (2015) Monitoring and Prediction of Land Use/Land Cover Change using the Integration of Markov Chain Model and Cellular Automation in the Southeastern Tertiary Hilly Area of Bangladesh. International Journal of Sciences: Basic and Applied Research, 24 (4): $125-148$.

55. Schrojenstein Lantman J, Verburg PH, Bregt A, Geertman S (2011) Core principles and concepts in land-use modelling: a literature review. In: Koomen, E., Borsboom-van Beurden, J. (Eds.), Chapter 3 in Land-use Modelling in Planning Practice. Springer, New York.

56. Sohl T, Sayler K. (2008) Using the FORE-SCE model to project land-cover change in the southeastern United States. Ecological Modelling, 219 (s1-2), 49-65. doi:10.1016/j. ecolmodel.2008.08.003.

57. Stehman, SV. (1996) Estimating the Kappa coefficient and its variance under stratified random sampling.. Photogrammetric Engineering and Remote Sensing, 62: 401-407. 
58. Subedi P, Subedi, K, Thapa B (2013) Application of a hybrid cellular automaton-Markov (CA-Markov) Model in land-use change prediction: A case study of saddle creek drainage Basin, Florida. Applied Ecology and Environmental Sciences, 1, 126-132.

59. Tayyebi A, Perry PC, Tayyebi AH (2014) Predicting the expansion of an urban boundary using spatial logistic regression and hybrid raster-vector routines with remote sensing and GIS. International Journal of Geographical Information Science, 28 (4), 639-659. doi:10.1080/13658816.2013.845892.

60. Tripathi DK, Kumar M (2012) Remote sensing based analysis of land use/land cover dynamics in Takula Block, Almora District (Uttarkhand). Journal of Human Ecology 38(3):207-212.

61. Turner, Ruscher MG (2004) Change in landscape patterns in Georgia USA Land. Ecology 1(4):251- 421.

62. Usher MB (1992) Statistical models of succession. In Glenn-Lewin DC, Peet RK and Veblen TT (eds), Plant succession: theory and prediction. Chapman and Hall, New York pp.215-248.

63. van Asselen, S. and Verburg, PH (2013) Land cover change or land-use intensification: simulating land system change with a global-scale land change model. Global Change Biology, 19 (12), 3648-3667. doi:10.1111/gcb.12331.

64. van Beest FM, Mews, SElkenkamp S, Schuhmann P, Tsolak D, Wobbe T, Bartolino V, Bastardie F, Dietz R, von Dorrien C, Galatius A, Karlsson O, McConnell B, Nabe-Nielsen J, Olsen MT, Teilmann J \& Langrock R (2019) Classifying grey seal behaviour in relation to environmental variability and commercial fishing activity a multivariate hidden Markov model. Scientific Reports 9:5642, https://doi.org/10.1038/s41598-019-42109-w.

65. Verburg, PH, Dearing, JA, Dyke JG, van der Leeuw S, Seitzinger S, Steffen W, Syvitski, J (2016) Methods and approaches to modelling the Anthropocene. Global Environmental Change 39:328-340.

66. Verma P, Raghubanshi, , Srivastava, PK, Raghubanshi AS (2020) Appraisal of kappa-based metrics and disagreement indices of accuracy assessment for parametric and nonparametric techniques used in LULC classification and change detection. Model. Earth Syst. Environ. 6: 1045-1059. https://doi.org/10.1007/s40808020-00740-x.

67. Weng, Q (2002) Land use change analysis in the Zhujiang Delta of China using satellite remote sensing, GIS and stochastic modelling. Journal of Environmental Management, 64, 273-284. 
68. Ye B, Bai Z (2008) Simulating land use/cover changes of Nenjiang County based on CA Markov model, Computer and Computing Technologies in Agriculture 1:321-329.

69. Yu W, Zang S, Wu C, Liu W, Na X (2011) Analyzing and modeling land use land cover change (LUCC) in the Daqing City, China. Applied Geography 31(2):600-608. https://doi:10.1016/j.apgeog.2010.11.019.

70. Yuan F, Sawaya KE, Loeffelholz B, Bauer ME (2005) Land cover classification and change analysis of the Twin Cities (Minnesota) Metropolitan Area by multitemporal Landsat remote sensing. Remote Sensing of Environment 98:317-328.

71. Zhang R, Tang C, Ma S, Yuan, Gao L, Fan W (2011) Using Markov chains to analyze changes in wetland trends in arid Yinchuan Plain, China. Mathematical and Computer Modelling 54(3-4): 924-930, https://doi:10.1016/j.mcm.2010.11.017.

72. Zhou W, Troy A, Grove M (2008) Object-based land cover classification and change analysis in the Baltimore metropolitan area using multitemporal high resolution remote sensing data. Sensors 8(3):1613-1636.

Conflict of Interest: On behalf of all authors, the corresponding author states that they have no conflict of interest. 


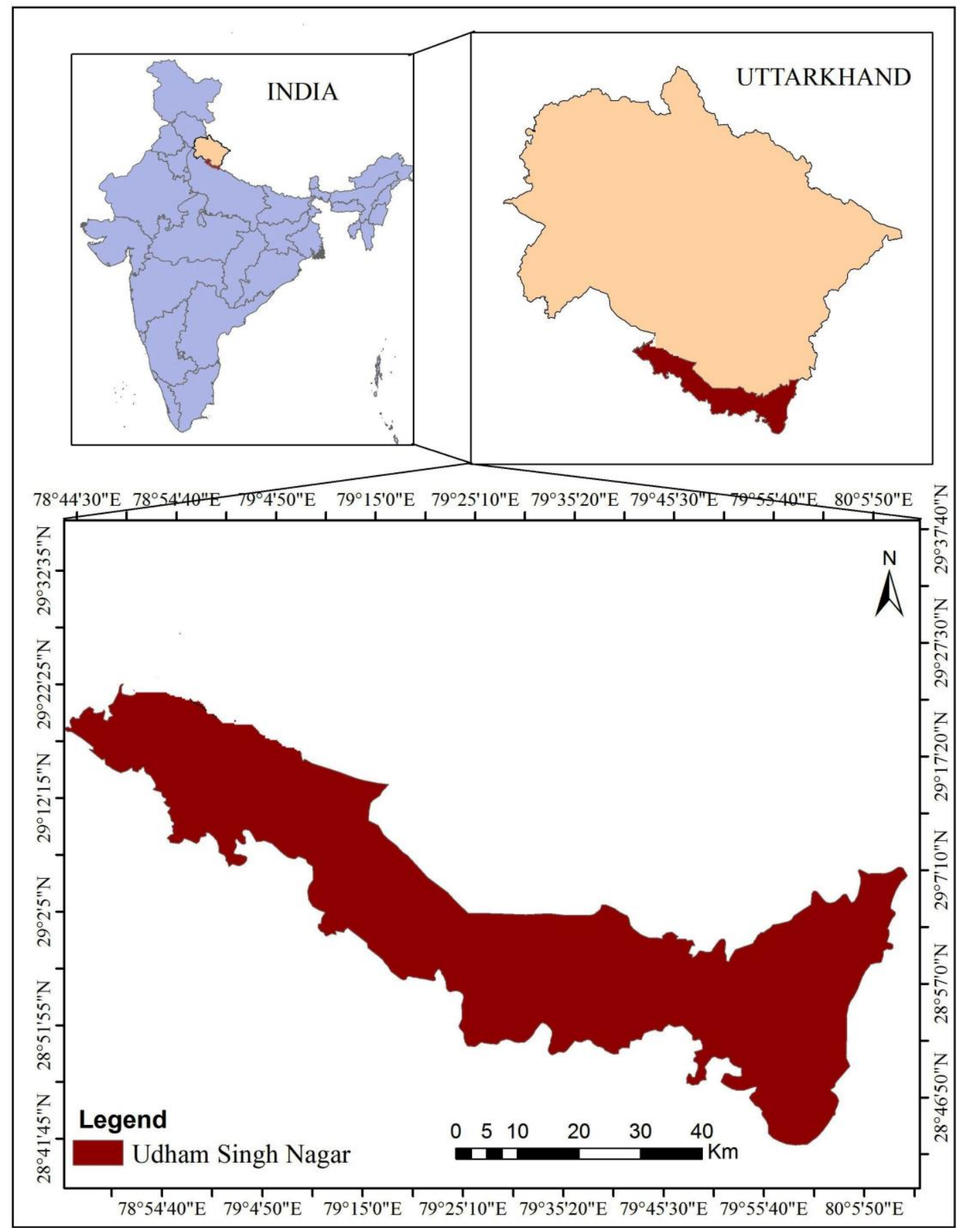

Figure 1. The study area map of Udham Singh Nagar 


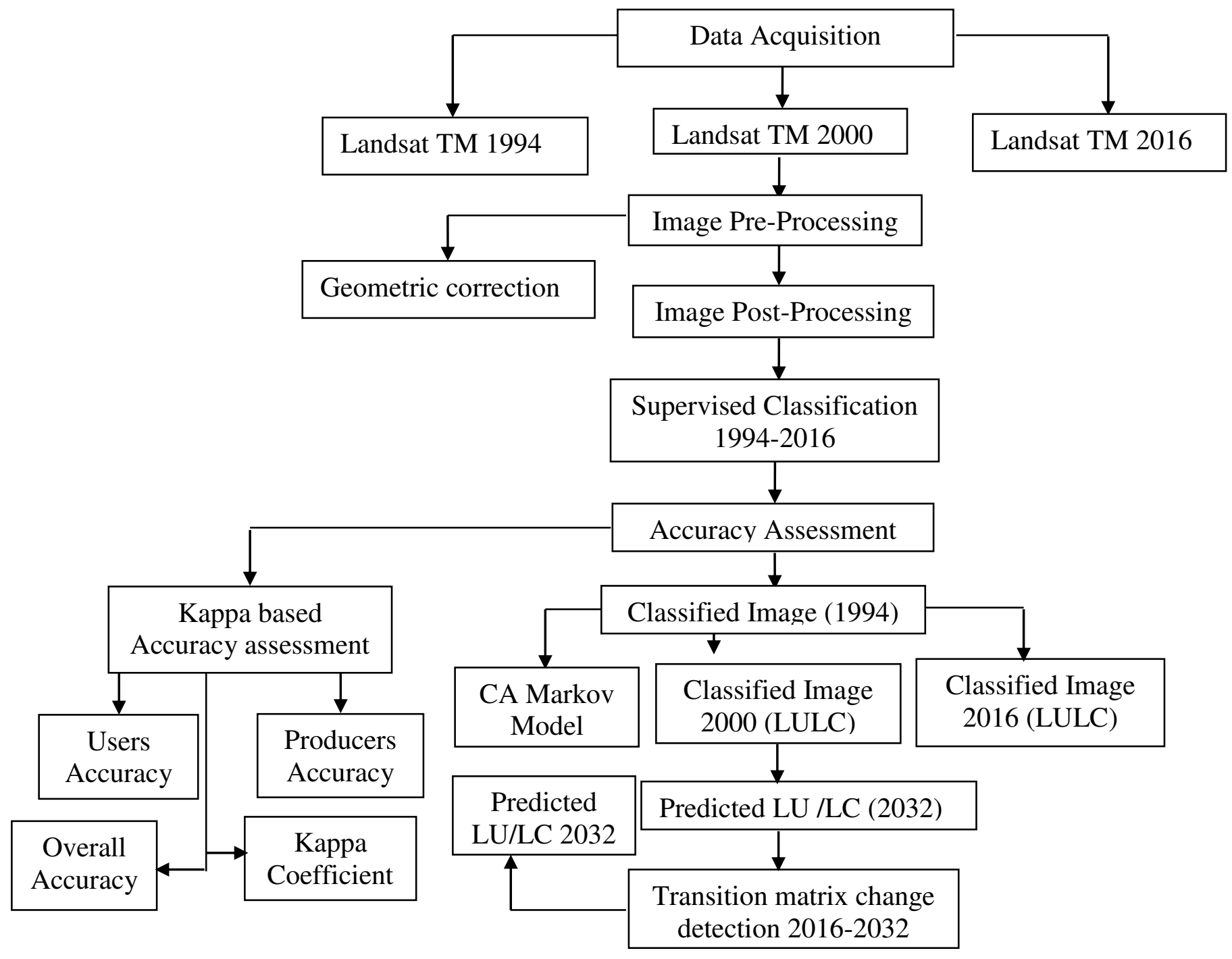

Figure 2. Flow chart methodology of the LULC CA Markov Model 


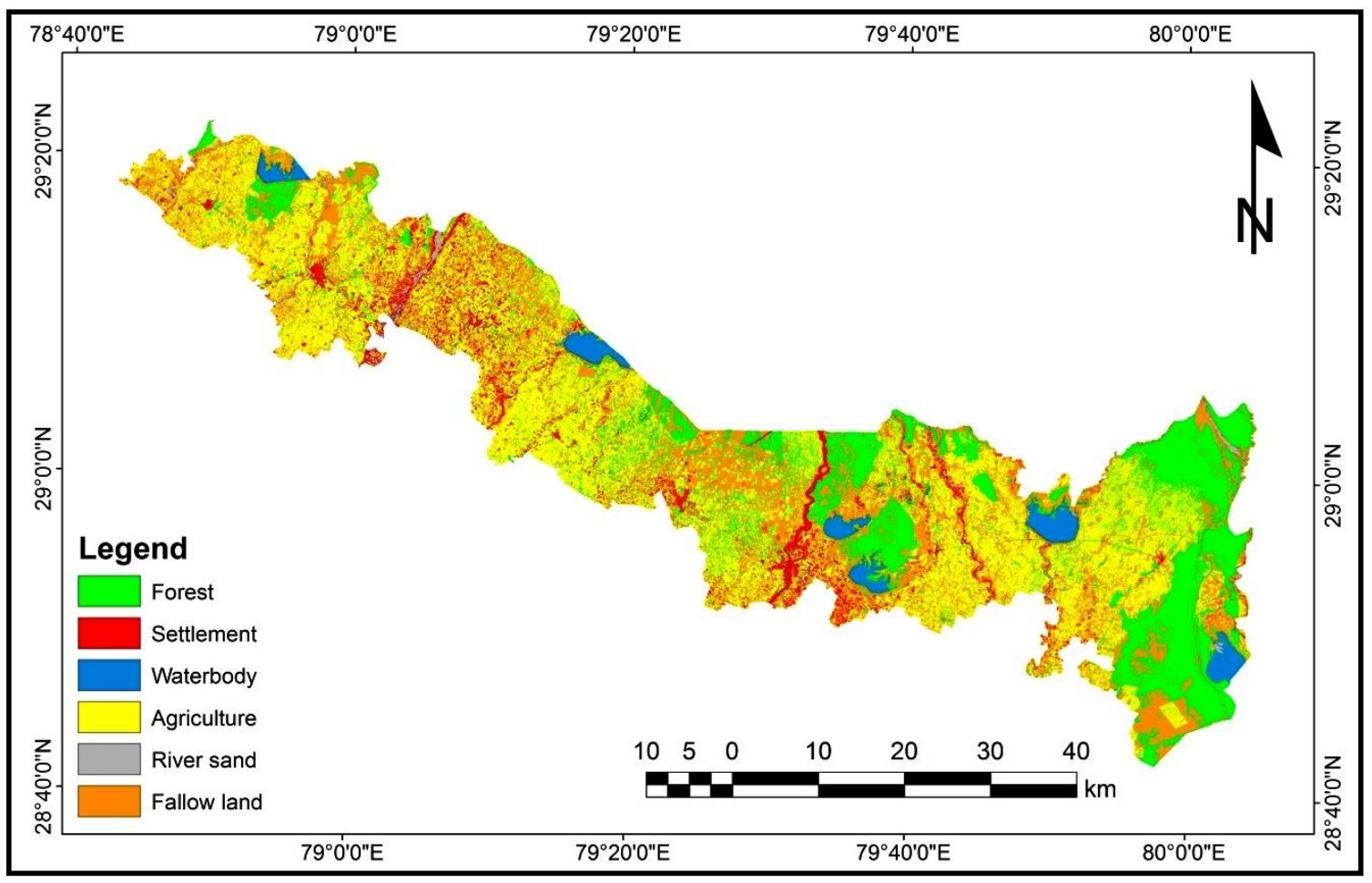

Figure 3. Land use Land cover map (1994)

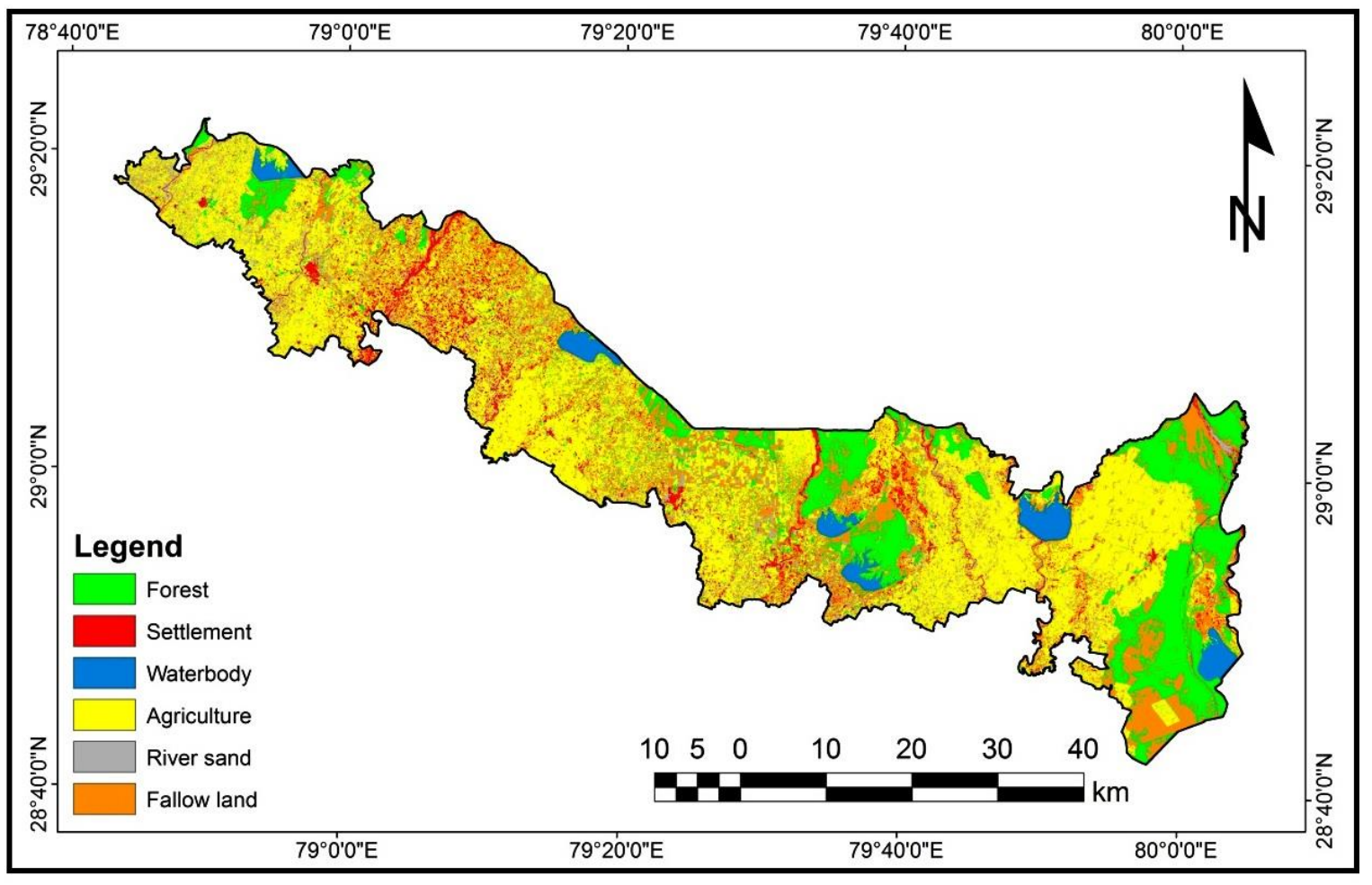

Figure 4. Land use land cover area map (2000) 


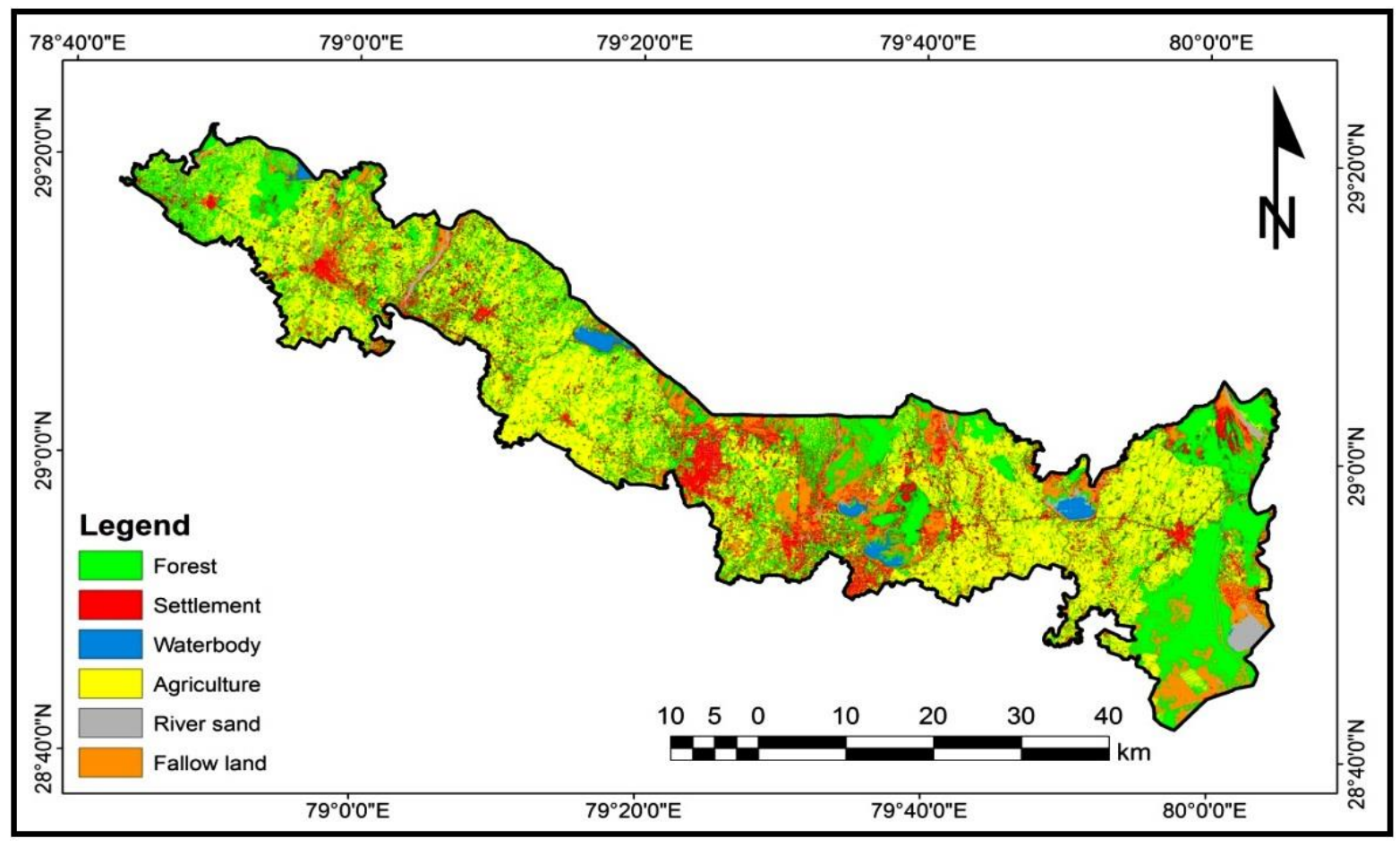

Figure 5. Land use land cover area map (2016)

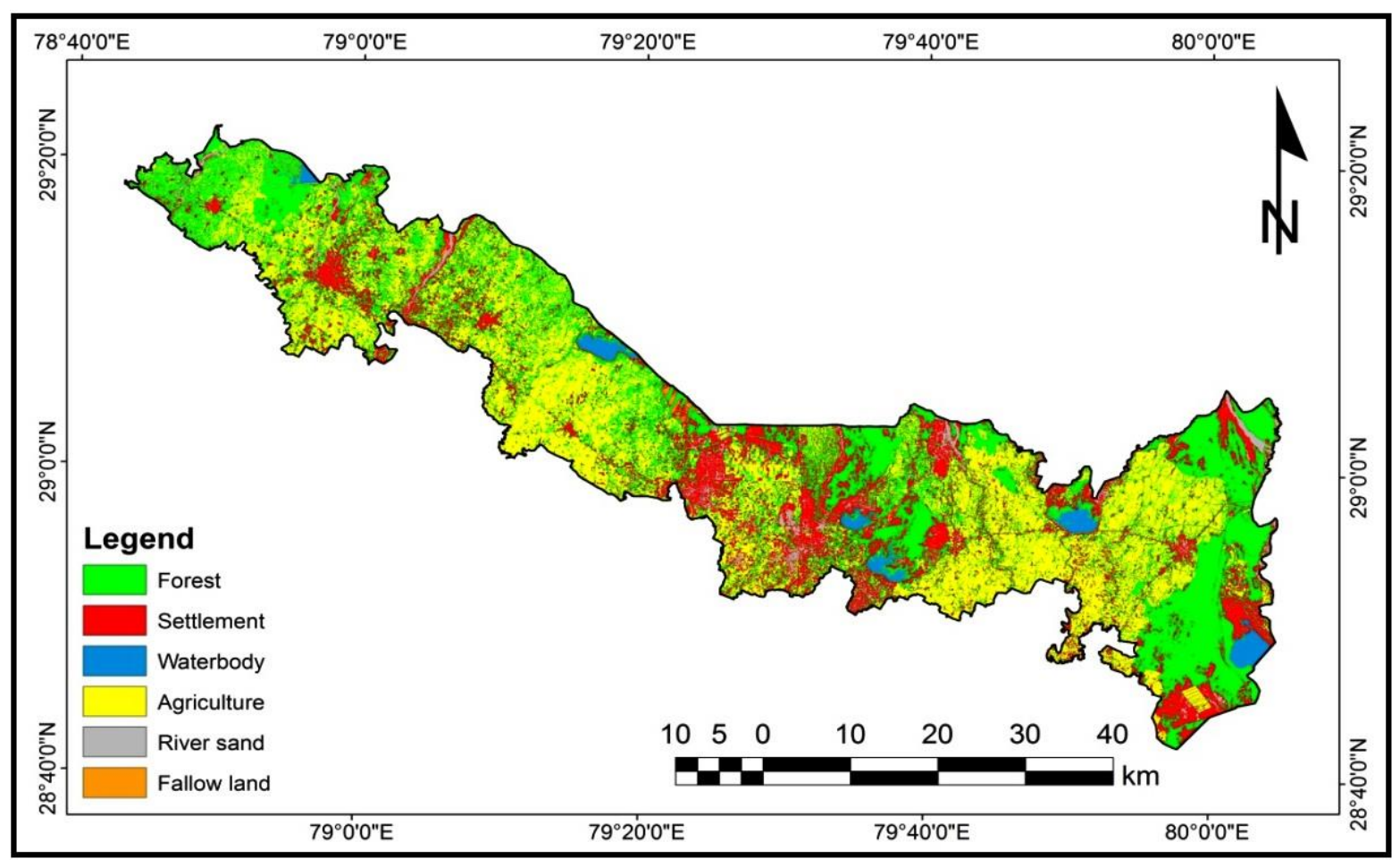

Figure 6. Predicted Land use Land cover map 2032 


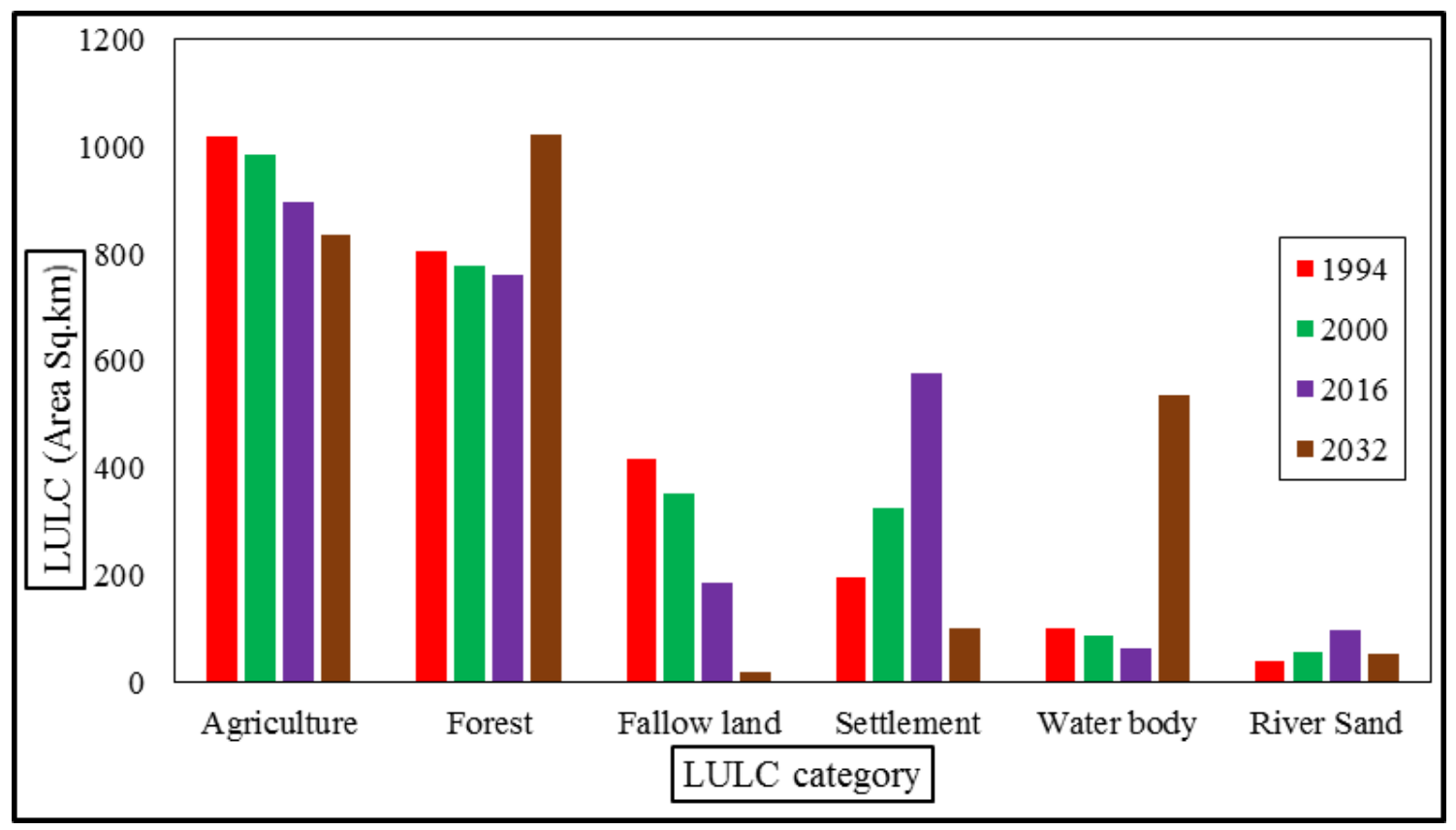

Figure 7. Area wise $\left(\mathrm{Km}^{2}\right)$ Land use Land cover change detection 1994 - 2032

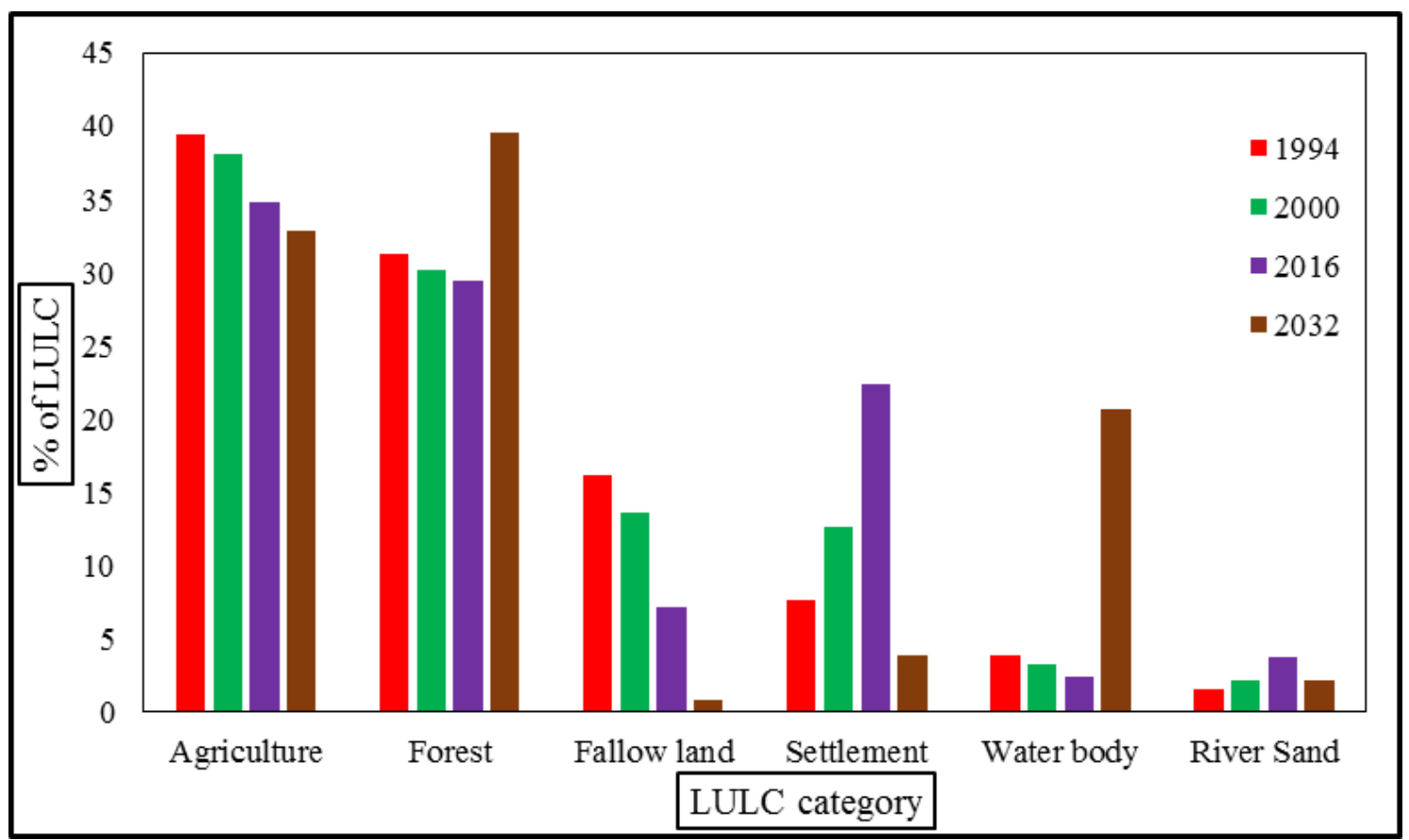

Figure 8. Percentage wise Land use Land cover change detection 1994 - 2032 


\section{Table 1: Satellite data specifications}

\begin{tabular}{cclcc}
\hline Datasets & Date of acquisition & \multicolumn{1}{c}{ Sensor } & Resolution (m) & Source \\
\hline Landsat 5 & Oct 25, 1994 & Thematic Mapper & 30 & USGS Earth Explorer \\
Landsat 7 & Oct 01, 2000 & Enhanced Thematic Mapper Plus & 30 & USGS Earth Explorer \\
Landsat 8 & Oct 21, 2016 & Operational Land Imager & 30 & USGS Earth Explorer \\
\hline
\end{tabular}

Table 2: LULC classification for three time periods for Udham Singh Nagar

\begin{tabular}{lcccccccc}
\hline $\begin{array}{l}\text { LULC } \\
\text { Classes }\end{array}$ & $\begin{array}{c}\text { Area }\left(\mathrm{Km}^{2}\right) \\
1994\end{array}$ & $\begin{array}{c}\% \text { of } \\
1994\end{array}$ & $\begin{array}{c}\text { Area }\left(\mathrm{Km}^{2}\right) \\
2000\end{array}$ & $\begin{array}{c}\text { \% of } \\
2000\end{array}$ & $\begin{array}{c}\text { Area }\left(\mathrm{Km}^{2}\right) \\
2016\end{array}$ & $\begin{array}{c}\% \text { of } \\
2016\end{array}$ & $\begin{array}{c}\text { Overall } \\
\text { changes }\end{array}$ & $\begin{array}{c}\text { \% of LULC } \\
\text { changes }\end{array}$ \\
\hline Agriculture & 1019.14 & 39 & 984.13 & 38 & 897.39 & 35 & 121.75 & 14 \\
Forest & 806.34 & 31 & 778.76 & 30 & 761.64 & 30 & 44.7 & 5 \\
Fallow land & 417.08 & 16 & 351.53 & 14 & 186.37 & 7 & 230.71 & 26.5 \\
Settlement & 196.89 & 8 & 326.04 & 13 & 576.78 & 22 & 379.89 & 44 \\
Water body & 101.63 & 4 & 85.76 & 3 & 62.72 & 2 & 38.91 & 4.5 \\
River Sand & 40.31 & 2 & 55.17 & 2 & 96.49 & 4 & 56.18 & 6 \\
\hline Total & 2581.39 & 100 & 2581.39 & 100 & 2581.39 & 100 & 872.14 & 100 \\
\hline
\end{tabular}

Table 3: Area in $\mathrm{Km}^{2}$ of Udham Singh Nagar 2032

\begin{tabular}{lll}
\hline Class Name & Area in $\left(\mathrm{Km}^{2}\right)$ & Area in \% \\
\hline
\end{tabular}




\begin{tabular}{ccc}
\hline Agriculture & 847.78 & 33 \\
Forest & 1021.78 & 39 \\
Fallow land & 22.08 & 1 \\
River sand & 99.92 & 4 \\
Settlement & 533.87 & 21 \\
Water body & 55.93 & 2 \\
\hline Total & 2581.39 & 100 \\
\hline
\end{tabular}

Table 4. Accuracy Assessment Error Matrix of classified image (1994)

\begin{tabular}{|c|c|c|c|c|c|c|c|c|c|}
\hline LULC & & & & & Water & River & & Producers & Users \\
\hline Classification & Agriculture & Forest & Fallow land & Settlement & body & Sand & Total & Accuracy & Accuracy \\
\hline Agriculture & 49 & 3 & 2 & 1 & 2 & 2 & 59 & 77.77 & 83.05 \\
\hline Forest & 3 & 42 & 3 & 3 & 4 & 1 & 56 & 76.36 & 75 \\
\hline Fallow land & 2 & 3 & 37 & 2 & 2 & 2 & 48 & 77.08 & 77.08 \\
\hline Settlement & 4 & 2 & 3 & 30 & 2 & 1 & 42 & 76.92 & 71.42 \\
\hline Water body & 3 & 3 & 1 & 1 & 33 & 2 & 43 & 75 & 76.74 \\
\hline River Sand & 2 & 2 & 2 & 2 & 1 & 28 & 37 & 77.77 & 75.67 \\
\hline Total & 63 & 55 & 48 & 39 & 44 & 36 & 285 & - & - \\
\hline
\end{tabular}




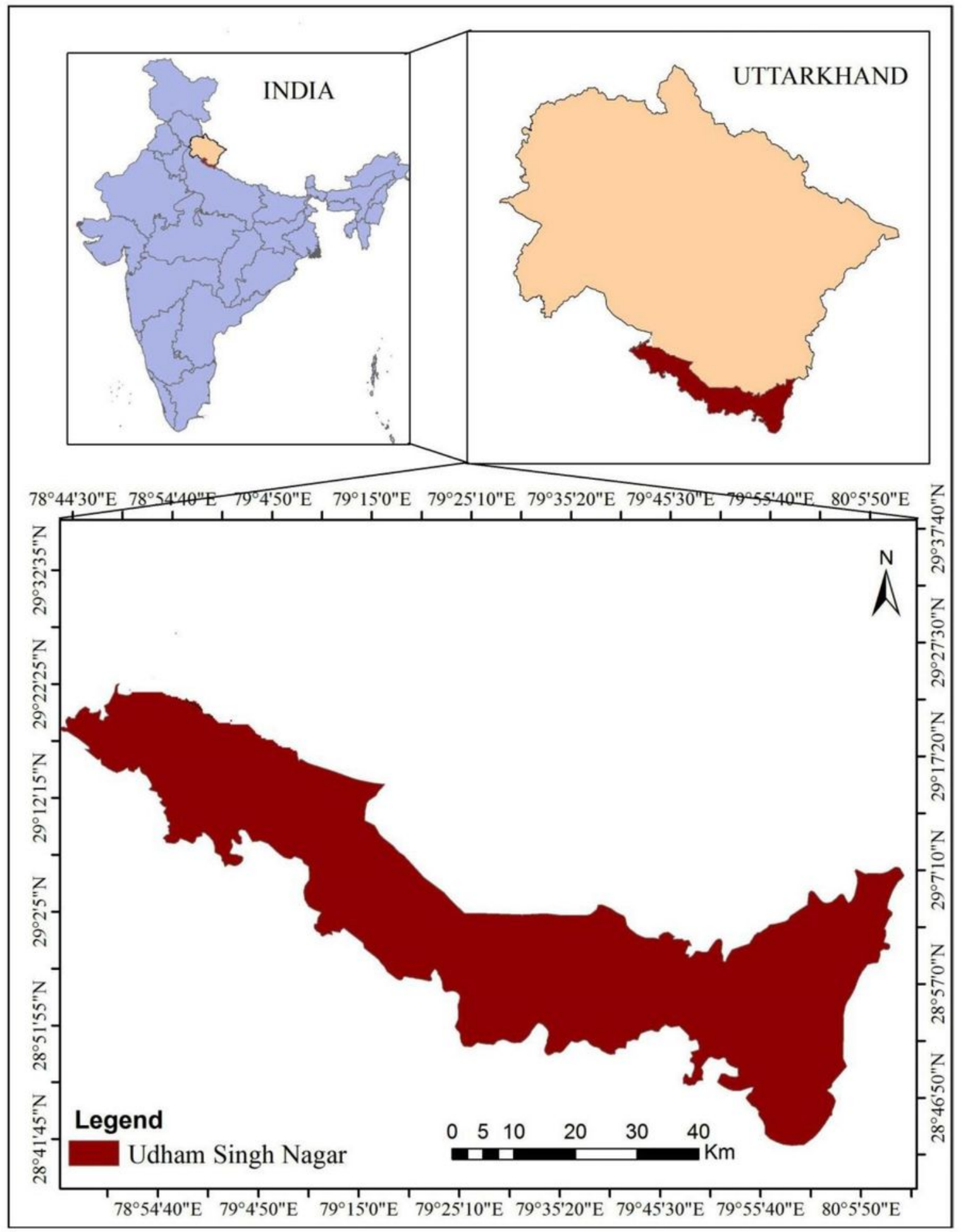

\section{Figure 1}

The study area map of Udham Singh Nagar Note: The designations employed and the presentation of the material on this map do not imply the expression of any opinion whatsoever on the part of Research 
Square concerning the legal status of any country, territory, city or area or of its authorities, or concerning the delimitation of its frontiers or boundaries. This map has been provided by the authors.

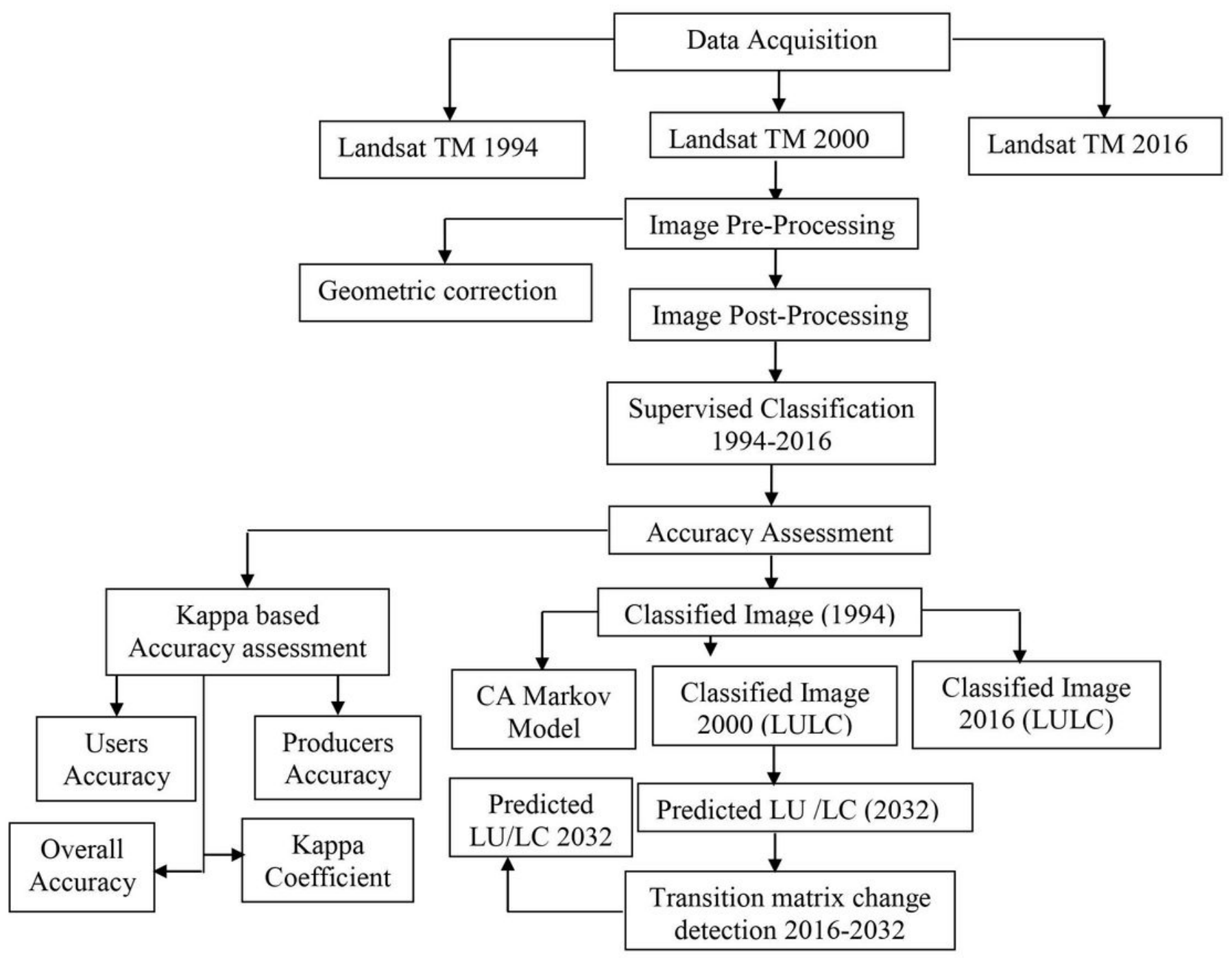

Figure 2

Flow chart methodology of the LULC CA Markov Model 


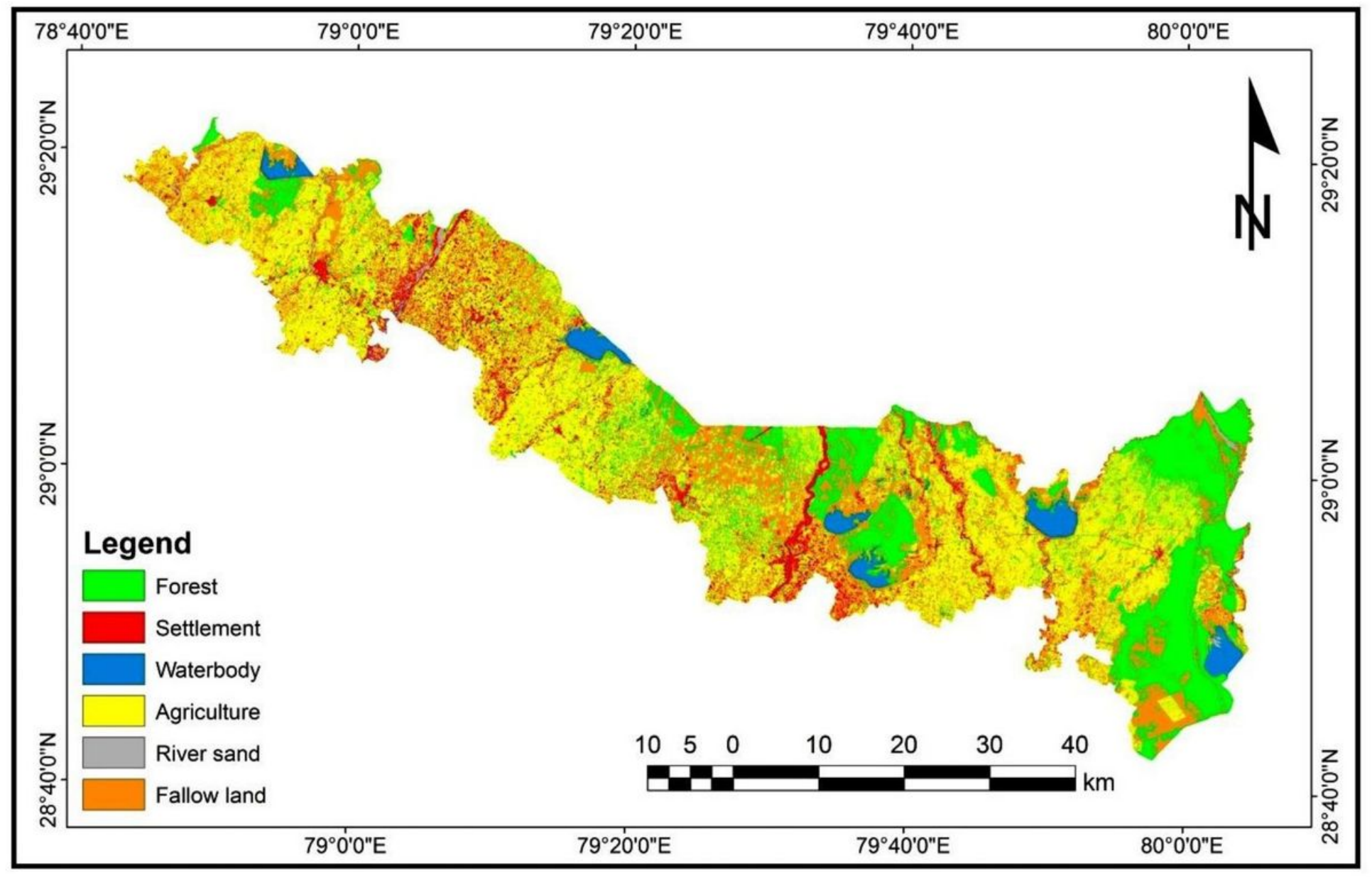

Figure 3

Land use Land cover map (1994) 


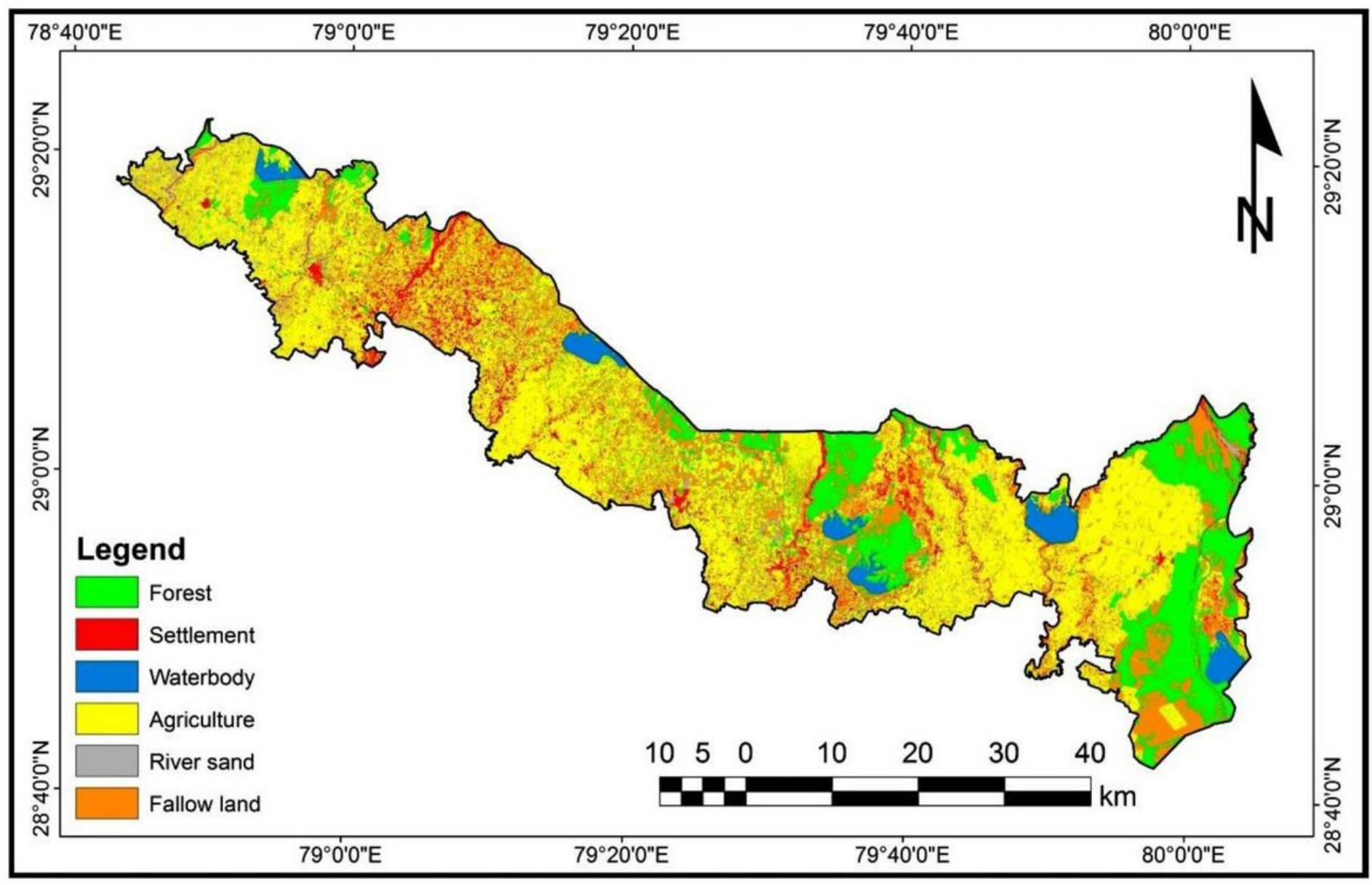

Figure 4

Land use land cover area map (2000) 


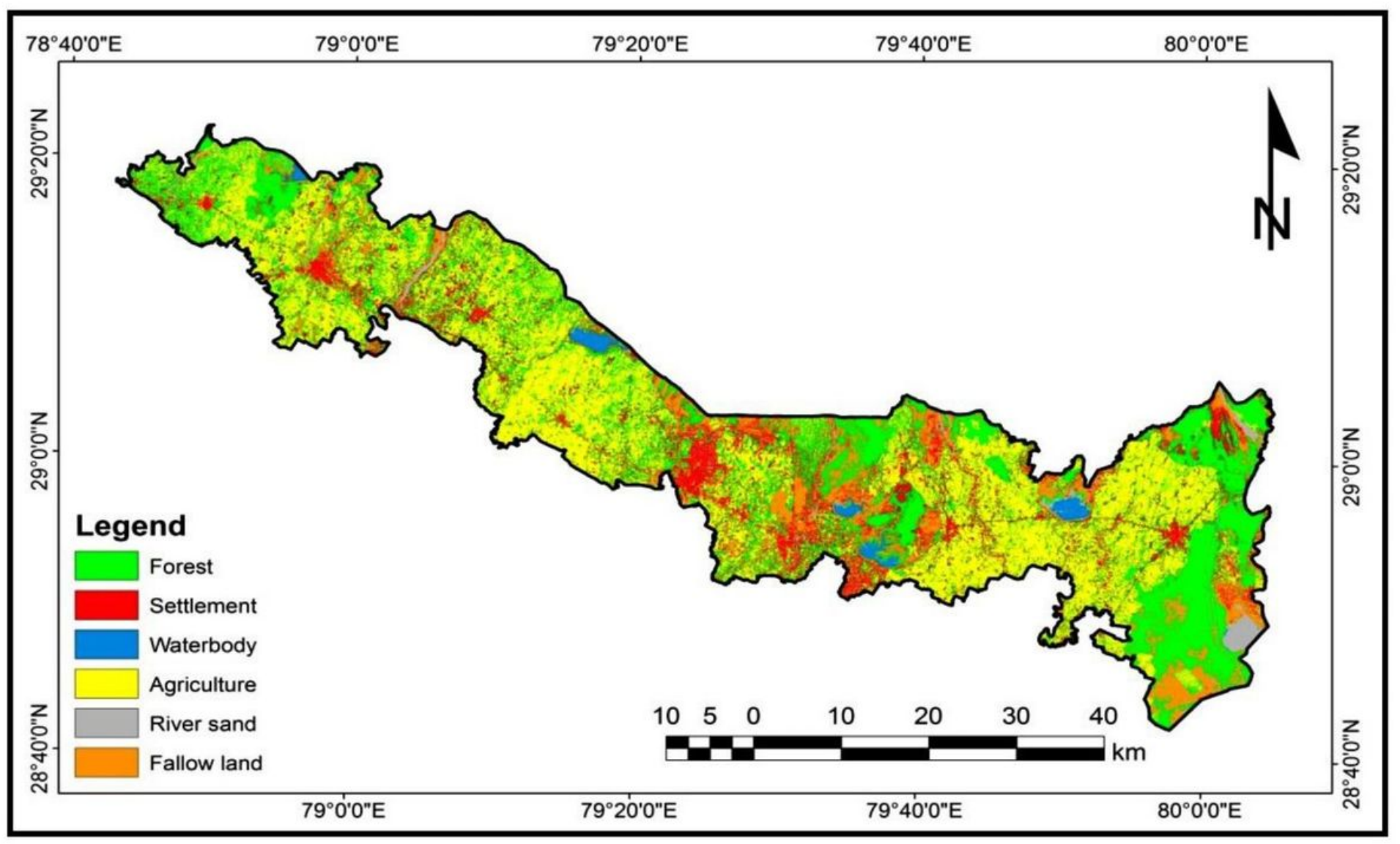

Figure 5

Land use land cover area map (2016) 


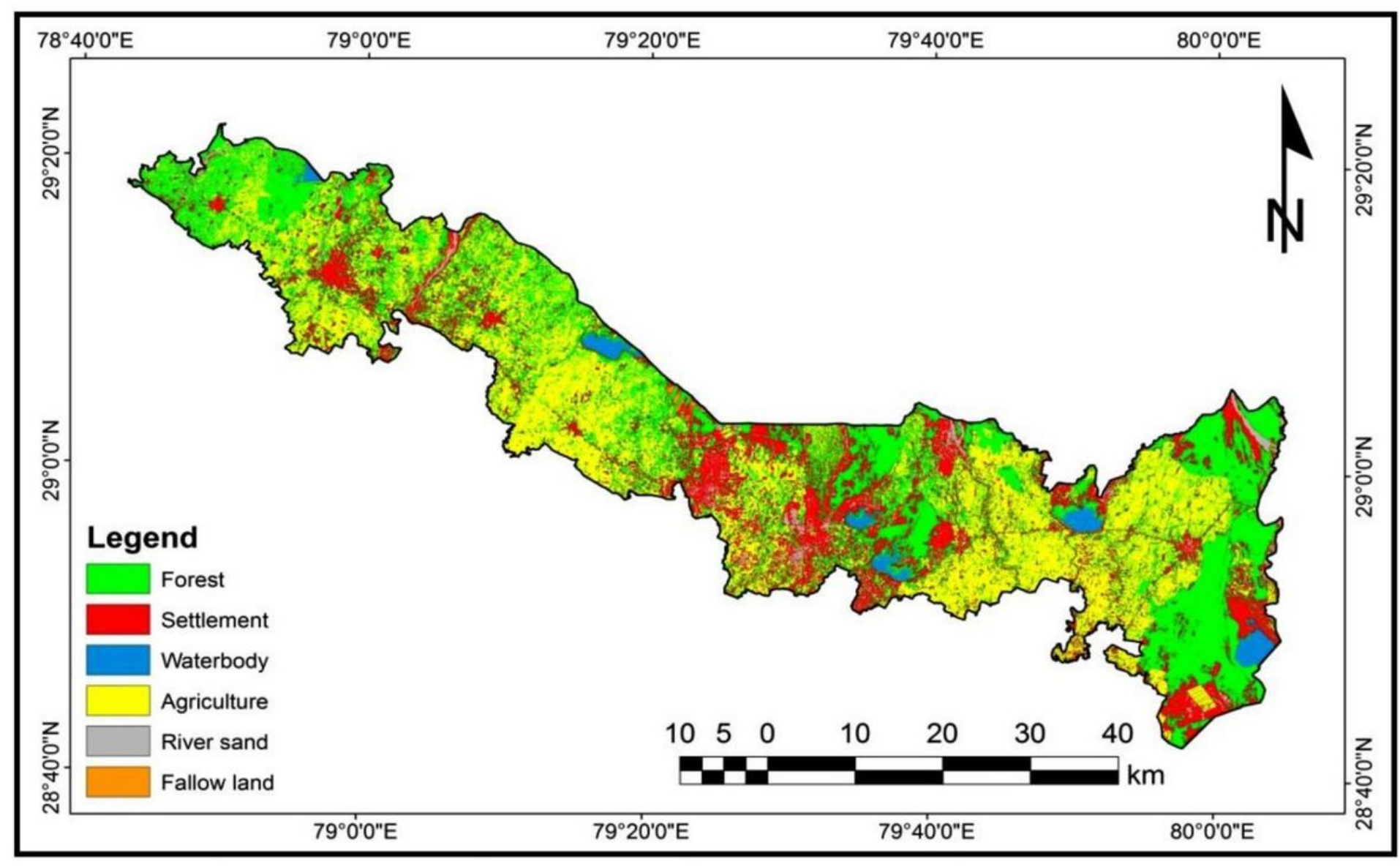

Figure 6

Predicted Land use Land cover map 2032 


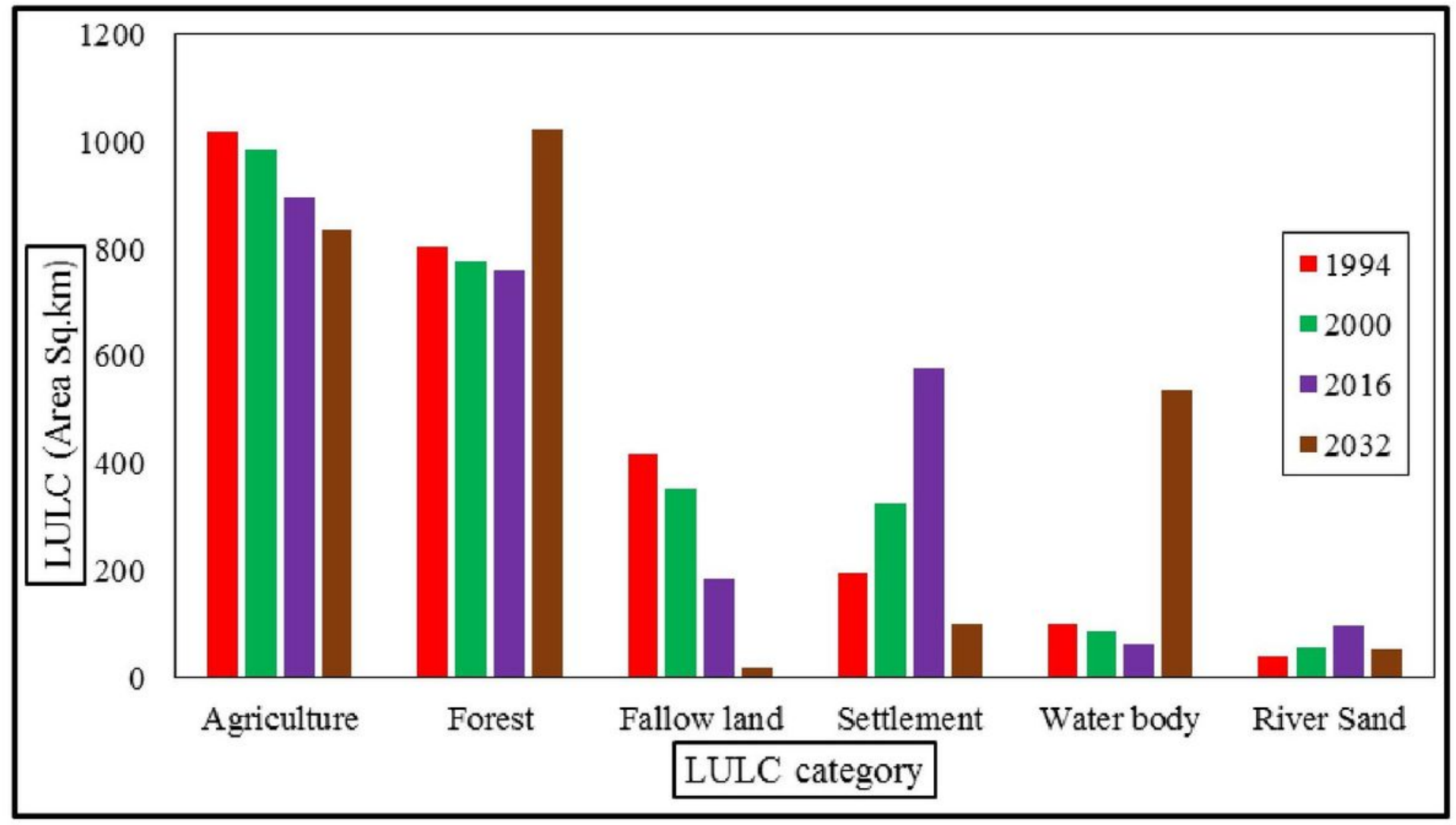

Figure 7

Area wise (Km2) Land use Land cover change detection 1994 - 2032

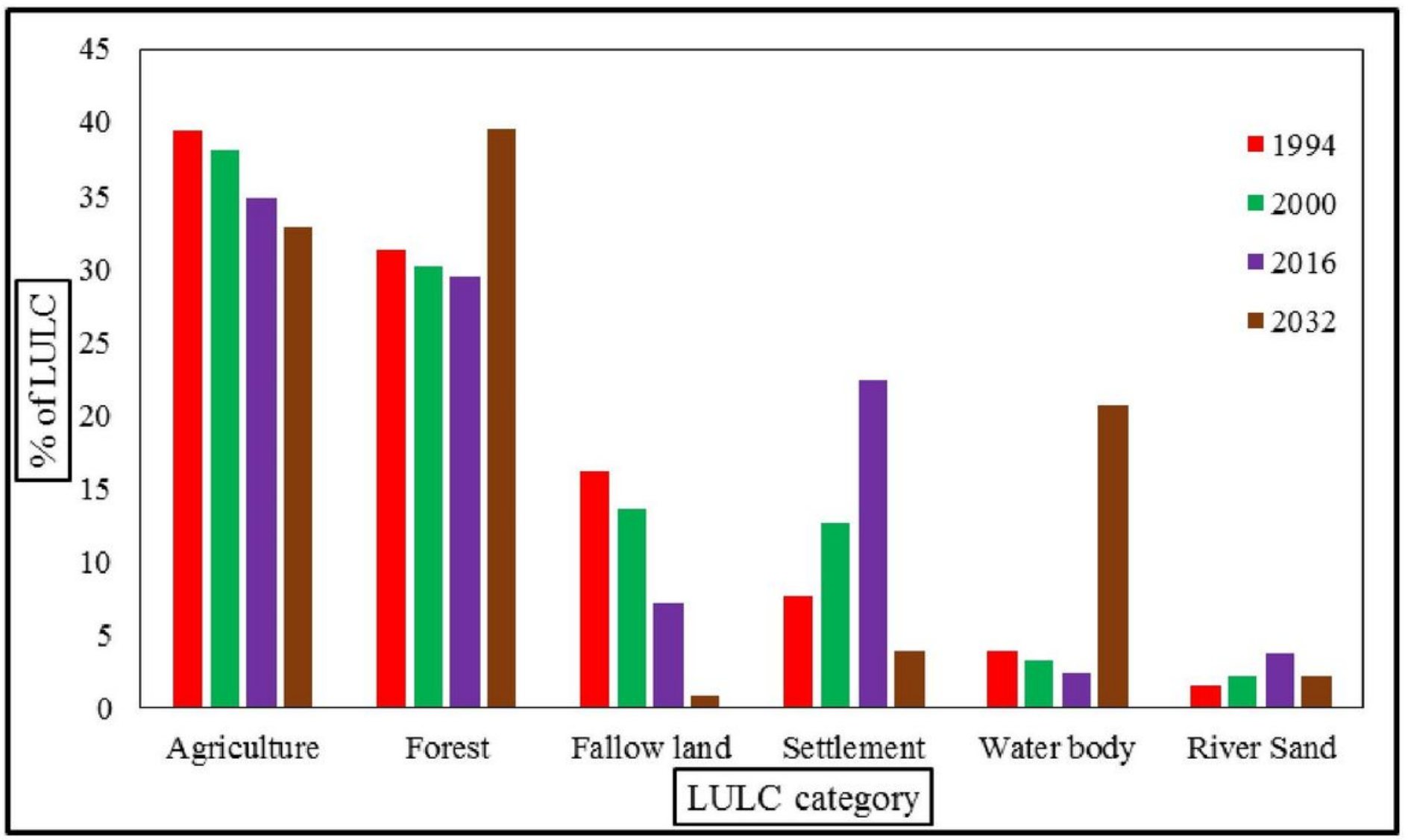


Figure 8

Percentage wise Land use Land cover change detection 1994 - 2032 